\title{
EXPERIMENTAL ANALYSIS OF A HYBRID DRYER
}

\author{
A. G. Ferreira ${ }^{\mathrm{a}}$, \\ A. L. T. Charbel ${ }^{\text {, }}$, \\ R. L. Pires ${ }^{b}$, \\ J. G. Silvab, \\ and C. B. Maia ${ }^{\mathrm{c}}$ \\ ${ }^{a}$ Centro Federal de Educação Tecnológica de Minas \\ Gerais, Cefet-MG. CP. 30480-000. Av. Amazonas, \\ 5253. Nova Suiça. BH/MG. Brasil. \\ agferreira@deii.cefetmg.br \\ ${ }^{\mathrm{b}}$ Centro Universitário de Belo Horizonte Uni-BH. \\ Departamento de Ciências Exatas e Tecnologia. \\ CP. 30455-610. Av. Professor Mário Werneck, 1685. \\ Estoril. BH/MG. Brasil. \\ c Pontifícia Universidade Católica de Minas Gerais. \\ Departamento de Engenharia Mecânica. \\ CP. 30535-901. Av. Dom José Gaspar, 500. \\ Coração Eucarístico. BH/MG. Brasil
}

\section{ABSTRACT}

Artificial dryers promote a high-quality food drying, in spite of the considerable energy consumption. Solar dryers use only solar energy to heat the drying airflow; nevertheless, it is not possible to control the airflow thermal conditions. Hybrid solar dryers arise as an interesting option to reduce the drying costs (compared to the artificial dryer's costs). Hybrid solar dryers improve the quality of the final product due to the control of the thermal drying condition. This paper presents an experimental analysis of an innovative hybrid solar-electrical dryer. This dryer consists of two chambers: solar chamber and drying chamber with electrical air heater. An experimental evaluation of the airflow in the device was performed and the average values of the temperature and the mass flow were presented as a function of the ambient conditions. To determine the performance of the proposed dryer, banana slices were dried in the device and the results were compared with natural sun drying and artificial drying.

Keywords: hybrid dryer, experimental analysis, bananas drying

\section{NOMENCLATURE}

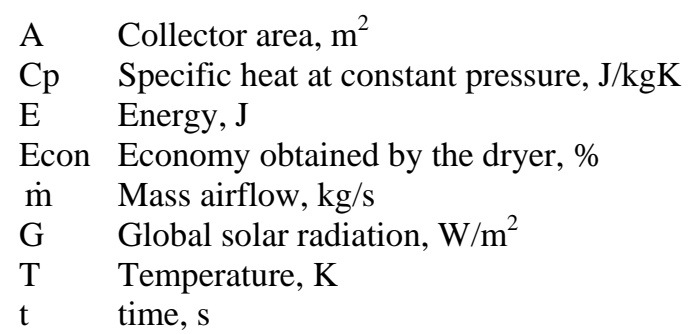

\section{Greek symbols}

$\eta \quad$ Collector efficiency, \%

\section{Subscripts \\ amb Ambient \\ out Outlet airflow \\ c Useful \\ s Solar \\ T Global absorbed}

\section{INTRODUCTION}

Dehydration arises as a suitable method to food preservation and to reduce the significant losses observed in Brazil (Vilela et al., 2003; Silva et al., 2003; Junqueira and Luengo; 1996). Natural sun drying is probably the oldest method to food preservation. However, it has several drawbacks, such as difficulty to control the rate of drying, insect infestation and microbial contamination. Replacing natural sun drying by artificial drying or by solar drying can significantly reduce these drawbacks and the losses caused by them (Silva, 2000). Nevertheless, the drying air characteristics in solar dryers depend on ambient conditions, what can reduce the final product's quality (Mühlbauer et al., 1996). Artificial drying requires higher operational costs, what can be unfeasible to some applications (Bena and Fuller; 2002). In this context, hybrid solar dryers arise as an interesting solution. The characteristics of the drying air can be controllable, improving the quality of dried products and the drying costs can be reduced, comparing with artificial drying.

A hybrid solar-electrical dryer was built, composed of a solar chamber (in which the air is heated) and of a drying chamber (Fig. 1). The solar chamber is inclined at $30^{\circ}$ from horizontal, opened at its edges, with $1.50 \mathrm{~m}$ of length, $1.20 \mathrm{~m}$ of width and $0.20 \mathrm{~m}$ of internal height. The walls of the solar collector were built with galvanized steel plates, painted in black, thermally insulated with wool glass and covered with galvanized steel plates painted in gray. The solar chamber is covered with glass. 


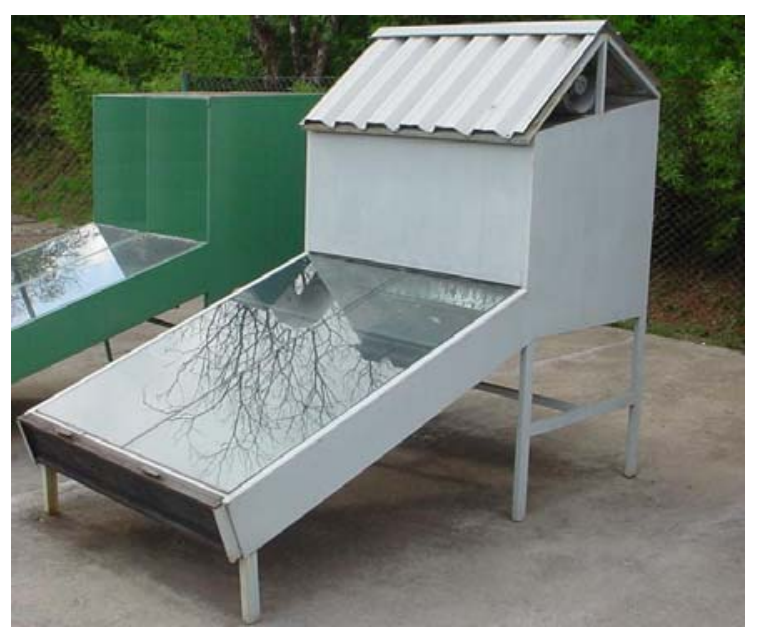

Figure 1. Hybrid solar-electrical dryer

The drying chamber has $0.90 \mathrm{~m}$ of length, $1.20 \mathrm{~m}$ of width and $0.96 \mathrm{~m}$ of height. It was built using galvanized steel plates, thermally insulated with wool glass and covered with galvanized steel plates painted in gray. To complement solar heating, an auxiliary heating system was installed on the bottom of the drying chamber. The auxiliary heating system is composed of 20 incandescent lamps of 100 $\mathrm{W}$ each. To allow the drying air exit, a $0.20 \mathrm{~m}$ diameter chimney (with an exhauster) was installed on the top of the dryer. Eight trays ( $0.74 \mathrm{~m} \mathrm{x} 0.52 \mathrm{~m}$ ) were put inside the drying chamber, corresponding to an area of $3.08 \mathrm{~m}^{2}$. The products can be introduced and removed trough two doors, located on the back of the dryer. A thermostat was installed in the chimney to control the airflow temperature in the device outlet.

A portion of the incident solar radiation passes trough the glass cover and reaches the absorber in the solar chamber. Ambient temperature air inlets and is heated by convection, raising its temperature while it flows towards the drying chamber. If necessary, the auxiliary heating system heats the air in the entrance of the drying chamber. The drying air passes trough the drying trays, removing humidity from the products, and leaves the dryer trough the elbowshaped chimney. The artificial movement of the air is promoted by an exhauster placed inside the chimney.

The hybrid dryer is similar to the dryers proposed by El-Sebaii et al. (2002), Pangavhane et al. (2002) and Ekechukwu and Norton (1999). However, in these dryers, airflow temperature depends exclusively on the ambient conditions. The use of an auxiliary system to complement solar heating improves the quality of drying. Hybrid dryers were also proposed by other authors. Bena and Fuller (2002) proposed a hybrid dryer, in which the auxiliary energy is provided by biomass. Ivanova et al. (2003) used a geothermal source of energy to complement solar energy. Nandwani (2007) built a multi-purpose hybrid solar food processor, working also as a dryer, in which the auxiliary system is composed by an electric plate with a resistance.

The main purpose of this paper is to evaluate the performance of the built dryer. The global characteristics of the drying airflow were evaluated as a function of the ambient thermal conditions. Experimental tests were performed to evaluate the economic feasibility of the device. Drying of banana slices was performed using distinct methods to determine the technical feasibility of the dryer.

\section{EXPERIMENTAL PROCEDURE}

The main parameters affecting the performance of the dryer were measured. A pyranometer (Squitter model S2024) was used to measure the global radiation incident on the dryer. This device has a response time lower than $1 \mathrm{~s}$, operational temperature from $-30^{\circ} \mathrm{C}$ to $70^{\circ} \mathrm{C}$ and uncertainty of $5 \%$. Incoterm thermocouples were used to measure ambient temperature and the drying air temperature inside the dryer. In the range of operation from $-20^{\circ} \mathrm{C}$ to $150^{\circ} \mathrm{C}$, the uncertainties of the sensors are $1.2^{\circ} \mathrm{C}$. The velocity of drying air was measured with a $0.050 \mathrm{~m}$ diameter propeller anemometer (Homis), with a global uncertainty of $6 \%$. Weight loss of the product during the drying period was measured with a digital analytical balance, with uncertainty of $0.3 \mathrm{~g}$. Uncertainties of the measurement devices were obtained to a 95\% level of confidence. A metrological analysis was performed to minimize measurement errors. All these data were measured three times to reduce measurement uncertainties.

Three experiments were conducted to evaluate the operation of the dryer during 2007 autumn. The first experiment was performed without any products inside the dryer, to evaluate the dryer's ability to control the characteristics of the outlet airflow and to evaluate the optimum operational condition of the dryer. Ambient conditions (global solar radiation incident on the dryer and ambient temperature) and global thermal characteristics of the airflow (velocity and temperature) were measured with the auxiliary energy system operating.

The second experiment was intended to determine a global balance of energy in the dryer and to evaluate its economic feasibility. The incident global solar radiation (G), the ambient temperature and the outlet airflow velocity and temperature were measured without any products inside the dryer and the auxiliary energy system turned off. The solar energy incident on the device (Es) was determined by

$$
\mathrm{E}_{\mathrm{S}}=\int(\mathrm{G} \cdot \mathrm{A}) \mathrm{dt}
$$

in which A represents the collector area of the dryer.

The fraction of the solar energy used to raise the airflow temperature (Ec) was determined based on the mass airflow ( $\dot{\mathrm{m}})$, on the airflow specific heat at 
constant pressure (Cp) and the ambient $\left(\mathrm{T}_{\mathrm{amb}}\right)$ and outlet $\left(\mathrm{T}_{\text {out }}\right)$ airflow temperatures.

$$
\mathrm{E}_{\mathrm{C}}=\int \dot{\mathrm{m} C p}\left(\mathrm{~T}_{\text {out }}-\mathrm{T}_{\mathrm{amb}}\right) \cdot \mathrm{dt}
$$

The global absorbed energy required by the air to achieve $50^{\circ} \mathrm{C}\left(\mathrm{E}_{\mathrm{T}}\right)$ was determined by

$$
\mathrm{E}_{\mathrm{T}}=\int \dot{\mathrm{m} C p}\left(50^{\circ} \mathrm{C}-\mathrm{T}_{\mathrm{amb}}\right) \mathrm{dt}
$$

It is important to notice that $50^{\circ} \mathrm{C}$ is the temperature defined for the drying airflow in the experiments.

The collector efficiency can be defined by (Leon, 2002)

$$
\eta=\frac{E_{C}}{E_{S}}
$$

Finally, the economy obtained by the dryer, when compared with an artificial dryer without any thermal losses, can be determined by

$$
\text { Econ }=\frac{E_{C}}{E_{T}}
$$

The technical viability of the device was determined in the third experiment. Slices of banana were dried in three distinct situations and the results were compared. The bananas were put into three immersion baths, as recommended by Meloni (2003). After this, the bananas were hand peeled, cut into $5 \mathrm{~mm}$ thick slices and divided into four samples. The first sample was used to determine the initial moisture content. It was put into an oven with controlled temperature, humidity and time. After a defined period of time, the initial moisture content (in wet basis) was determined. The second sample was inserted into an electrical dryer (forced circulation oven). The third into the hybrid dryer and the fourth sample was directly exposed to the sun. In both dryers, the air temperature was fixed in $50^{\circ} \mathrm{C}$. It was observed in previous analysis that the volume flow provided by the electrical dryer was not suitable to the proposed drying. Therefore, it was installed a more powerful fan in the hybrid dryer, increasing its volume flow. To minimize errors, all the samples were subdivided into three sub samples. The drying curves were obtained for all the samples until the desired moisture content of $20 \%$ (wet basis) was achieved.

\section{RESULTS AND DISCUSSION}

The ability of the dryer to maintain the outlet airflow temperature in $50^{\circ} \mathrm{C}$ was evaluated in the first experimental test performed. The dryer was supposed to maintain this temperature, regardless external ambient conditions. The capacity of the dryer was determined based on the outlet airflow mass. This test was carried out on March 06, from 08:00 to 18:00.

The ambient air temperature and the outlet air temperature of the dryer over time are shown in Fig. 2. From the results in this figure, it is seen that the ambient air temperature varied from $(22.8 \pm 0.7)^{\circ} \mathrm{C}$ (at the beginning of the test) to $(31.9 \pm 0.7)^{\circ} \mathrm{C}$ at $14: 30$. The outlet air temperature varied from $(45.0 \pm 0.7)^{\circ} \mathrm{C}$ to $(52.3 \pm 0.7)^{\circ} \mathrm{C}$. It is important to notice that this range of variation was obtained due to the thermostat. A more accurate control of temperature could have been obtained if the thermostat used was adjusted; however, it could reduce the lifetime of the auxiliary system.

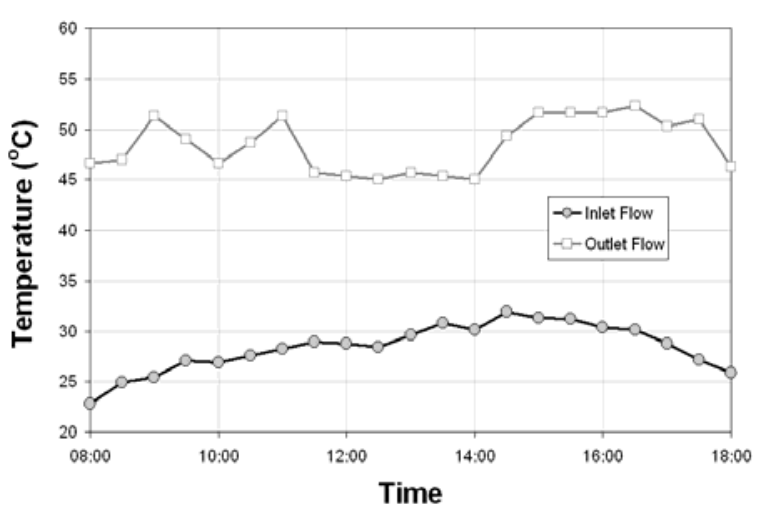

Figure 2. Inlet and outlet airflow temperatures during the first test

The incident solar radiation and the measured volume flow during the tests are shown in Fig. 3. It is seen that solar radiation increases with time, reaching its maximum value of $(1150 \pm 33) \mathrm{W} / \mathrm{m}^{2}$. The unexpected reductions observed on the solar radiation are due to clouds in the sky. The volume flow varied from $(4.9 \pm 0.2) \times 10^{-2} \mathrm{~m}^{3} / \mathrm{s}$ to $(6.3 \pm 0.2) \times 10^{-2} \mathrm{~m}^{3} / \mathrm{s}$. These variations are due to variations in the airflow temperature (that alter the buoyancy forces in the airflow inside the drying chamber) and due to variations on the electric net that drives the exhauster.

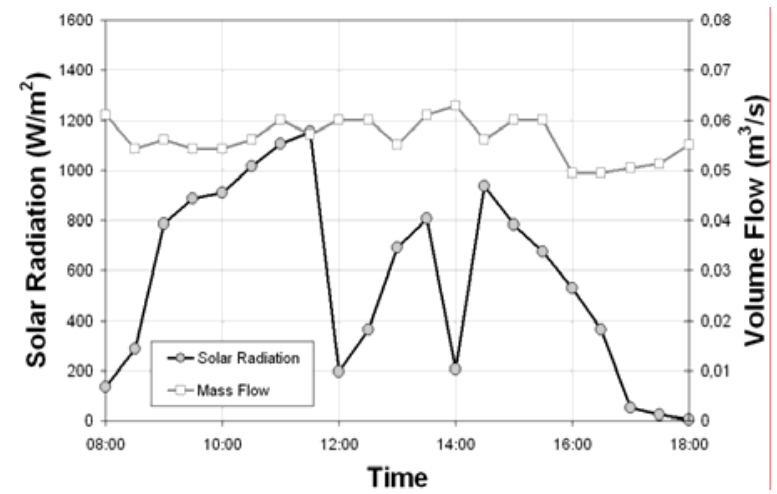

Figure 3. Solar radiation and volume flow during the first test 
According to Leon (2002), the drying capacity of a dryer can be determined as $4 \mathrm{~kg}$ of products per each square meter of drying trails. Since the prototype's area is $3.08 \mathrm{~m}^{2}$, the capacity of the dryer was estimated in $12 \mathrm{~kg}$. Leon (2002) also suggests the optimum volume flow as $0.0125 \mathrm{~m}^{3} / \mathrm{s}$ per $4 \mathrm{~kg}$ of products. According to this relation, the optimum volume flow of the dryer is $0.0375 \mathrm{~m}^{3} / \mathrm{s}$. It is seen that this volume flow represents about $80 \%$ of the minimum volume flow obtained in the experimental tests. However, this volume flow was obtained without any products inside the dryer. The volume flow obtained with the products inside the dryer will be reduced due to the head losses caused by the products. It is seen, therefore, that the device was well-designed for a $12 \mathrm{~kg}$ capacity.

The influence of the solar chamber on the amount of energy used to heat the drying air was determined in the second experimental test. It was also evaluated the economic viability of the dryer. The auxiliary energy system was turned off and there weren't any products inside the dryer. The test was performed in March 21, from 08:00 to 18:00.

The incident solar radiation is shown in Fig. 4. The maximum value reached was $(1059 \pm 30) \mathrm{W} / \mathrm{m}^{2}$. The solar radiation incident on the device was integrated over the test period, resulting in a total energy of 41 MJ. The airflow was able to absorb $18 \mathrm{MJ}$ of this energy. Based on these results, the collector efficiency of the dryer, obtained by Eq. (4), was $44 \%$. It is important to notice that the solar energy could not provide such amount of energy to the airflow. To reach $50^{\circ} \mathrm{C}$, the air should have to absorb approximately 48 MJ. Compared with an ideal artificial dryer (without thermal losses), the minimum economy of the dryer was $38 \%$. This is a very significant value, capable of ensuring the economic viability of the dryer.

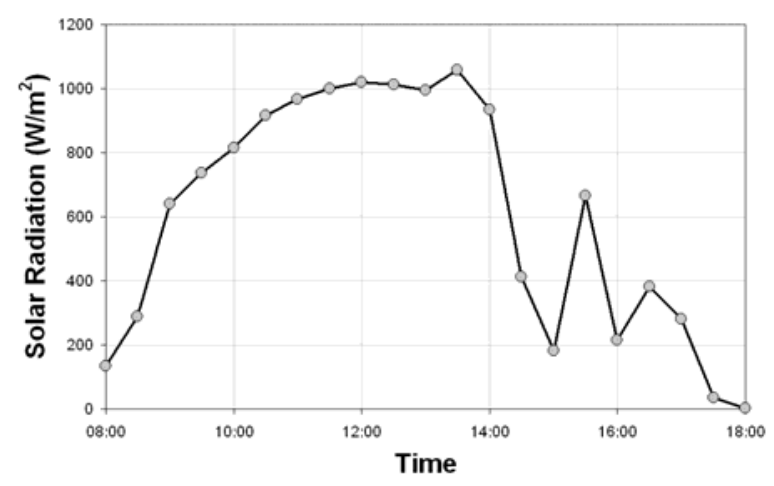

Figure 4. Solar radiation during the second test

The technical viability of the dryer was determined in the third experimental test, performed in March 28. The incident solar energy, obtained by the integration of the solar radiation, was $44 \mathrm{MJ}$. During the test, the ambient air temperature varied from de $(25.2 \pm 0.7)^{\circ} \mathrm{C}$ to $(32.2 \pm 0.7)^{\circ} \mathrm{C}$. The outlet air temperature varied from $(46.8 \pm 0.7)^{\circ} \mathrm{C}$ to
$(54.3 \pm 0.7)^{\circ} \mathrm{C}$. Comparison of the drying curves of bananas in the hybrid and electrical dryer with the obtained by natural sun drying is shown in Fig. 5 .

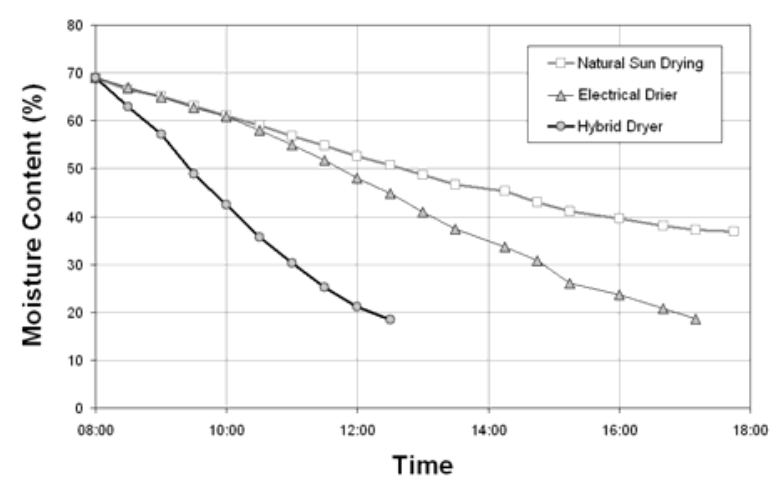

Figure 5. Drying curves of banana slices during the third test

The moisture content of bananas reached 20\% (wet basis) from an initial value of $69 \%$ (wet basis). It is seen that the desired final moisture of content was reached in $4 \mathrm{~h}$ by the bananas inside the hybrid dryer and in $8.5 \mathrm{~h}$ by the bananas inside the electrical dryer, while the bananas exposed to natural sun drying did not achieve this content in a 10 hour period. The faster drying of bananas inside the hybrid dryer is due to the higher volume flow and temperatures obtained in the hybrid dryer (The temperature achieved $55^{\circ} \mathrm{C}$, which reduced significantly the drying time) and to the absorption of radiation by the slices of banana, emitted by the auxiliary system lamps (providing a complementary heating of the products). However, the proposed hybrid dryer presented some disadvantages. The radiation emitted by the incandescent lamps was used to heat the dryer walls instead of heating the airflow, increasing the energy consumption required by the air to achieve $50^{\circ} \mathrm{C}$. Moreover, the products on the trays closer to the lamps drying in a faster rate than the products on the other trays, since the former absorbed more thermal radiation than the latter. It may overheat the products and alter its nutritional characteristics. It should be necessary to replace the lamps by electrical resistances to minimize these drawbacks.

\section{CONCLUSIONS}

Results from experimental tests performed in the hybrid dryer showed that the dryer can be used to dry up to $12 \mathrm{~kg}$ of bananas. The thermal characteristics of the drying air were relatively stable, providing a final product quality similar to that obtained in an artificial dryer.

The economic viability of the dryer was demonstrated. Compared with an artificial dryer, an economy of energy of approximately 38\% was obtained. 
Experimental runs for drying of banana slices were performed. Banana slices were exposed to natural sun drying in the hybrid dryer and in an artificial dryer and the drying curves obtained were compared. Results showed that the time required by the samples to reach the desired final moisture content was lower in the hybrid dryer when compared with natural sun drying and with the artificial dryer, to similar outlet air temperatures. Incandescent lamps used as an auxiliary energy system in the hybrid dryer provided a faster drying; however, the thermal losses were more significant and the products did not dry homogeneously. The products in the trays closer to the lamp presented a faster rate of drying.

When compared with artificial dryers, the proposed dryer is technically and economically viable. It represents a suitable alternative to dry agricultural products.

\section{ACKNOWLEDGEMENTS}

The authors are thankful to Centro Universitário de Belo Horizonte, Uni-BH, for the financial support and to Eng. José Geraldo Coura for his help on the design and construction of the hybrid solar dryer.

\section{REFERENCES}

Aguirre, J. M.; Gasparino Filho, J., 1999, Desidratação de Frutas e Hortaliças, Manual Técnico do Instituto de Tecnologia de Alimentos (ITAL), Campinas.

Bena, B. and Fuller, R. J., 2002, Natural Convection Solar Dryer With Biomass Back-up Heater, Solar Energy, Vol. 72, No.1, pp. 75-83.

Ekechukwu, O. V. and Norton, B., 1999, Review of Solar-energy Drying Systems II: an Overview of Solar Drying Technology, Energy Conversion and Management, Vol. 40, pp. 615-655.

El-Sebaii, A.A., Aboul-Enein, S., Ramadan, M. R. I. and El-Gohary, H. G, 2002, Experimental Investigation of an Indirect Type Natural Convection Solar Dryer, Energy Conversion and Management, Vol. 43, pp. 2251-2266.

Ivanova, D., Enimanev, K. and Andonov, K., 2003, Energy and Economic Effectiveness of a Fruit and Vegetable Dryer, Energy Conversion and Management, Vol. 44, pp. 763-769.

Junqueira, A. H. and Luengo, R. F. A., 1999, Mercados Diferenciados, Embrapa Hortaliças, Circular Técnica, No 16, pp 1-7.

Leon, M. A., Kumar, S. and Bhattacharya, S. C., 2002, A Comprehensive Procedure for Performance Evaluation of Solar Food Dryers, Renewable and Sustainable Energy Reviews, Vol. 6, pp 367-393.

Meloni, P. L. S., 2003, Produção de Frutas Desidratadas, Apostila da Sociedade Mineira de Engenheiros Agrônomos (SMEA).

Mühlbauer, W.; Müller, J.; Esper, A. and Bux, M., 1996, Secagem Solar e ao Sol para Produtos
Agrícolas e Florestais (Translation to Portuguese), Universidade de Hohenheim/Instituto para Engenharia Agrícola nos Países Tropicais e Subtropicais, Stuttgart/Alemanha.

Nandwani, S. S.; 2007. Design, construction and study of a hybrid solar food processor in the climate of Costa Rica. Renewable Energy, Vol. 32, pp. 427/441.

Pangavhane, D. R., Sawhney, R. L. and Sarsavadia, P. N., 2002, Design, Development and Performance Testing of a New Natural Convection Solar Dryer, Energy, Vol. 27, pp. 579-590.

Silva, C. S.; Pedrosa, J. M. Y.; Rua, P. S.; Abreu, C. L. M.; Pântano, S. C.; Vieira C. R. Y. I. and Brizola, R. M. O., 2003, Avaliação Econômica das Perdas de Banana no Mercado Varejista: Um Estudo de Caso, Ver. Brás. Frutic., Jaboticabal-SP, Vol. 25, No 2, pp. 229-234.

Silva, J. S., 2000, Secagem e Armazenagem de Produtos Agrícolas, Editora Aprenda Fácil, Viçosa, Brazil.

Vilela, N. J.; Lana, M. M. and Makishima, N. O., 2003, O Peso da Perda de Alimentos para a Sociedade: O Caso das Hortaliças, Horticultura Brasileira, Brasília, Vol. 21, No 2, pp. 141-143. 